\title{
Major Agricultural Trade Volume in Ethiopia: Trade Balance and Exchange Rate Relations a Structural Break Analysis (Using Stability Chow Test, CUSUM and CUSUM Squared Residuals) Gebeyehu AB*
}

Master of Science in Economic Policy Analysis, Department of Economics, Aksum University, Axum, Ethiopia

\begin{abstract}
The paper attempted to analyze Trade volume in seven major agricultural products in Ethiopia. The data revealed in most cases the volume of export is less than volume of import. Trade balance and exchange rate based on impulse response function and the forecast error variance decompositions. The short run effect of devaluation can be captured by the impulse response functions. Impulse response results show that trade balance in Ethiopia after real depreciation of currency follows J-curve patter. More importantly the obtained estimates suggest that upon real depreciation in the first three years trade balance deteriorates ('short run') and subsequently improves. The forecast error variance decomposition for each variable reveals the proportion of the movement in this variable due to its own shocks versus the shocks in other variables. Further information on the linkages between the trade balance and its determinants can be obtained from variance decompositions, which measure the proportion of forecast error variance in a variable that is explained by innovations (impulses) in itself and the other variables. Discussion was conducted on analyzing trade balance variance decomposition over a period of 10 years. The variance decomposition of trade balance reveals that changes in its own shock, trade balance is the predominant source of variation in the logarithm of trade balance. The result showed own series shock of trade balance explain most of the forecast error variance of the series in both based on VAR and VECM. The change in the real effective exchange rate represents the second source of variation in trade balance with a percentage of $1.4 \%$, and $1.28 \%$ in the second and third year forecast horizons based on VAR respectively. Finally, the results also prove the relative ineffectiveness of the industrial production index in affecting trade balance in Ethiopia based on both in VAR and VECM.
\end{abstract}

Keywords: Trade balance; Real exchange rate; Impulse response function; The forecast error variance decompositions

\section{Introduction}

The exchange rate is often discussed in macroeconomics because of its impact on the economy as a whole. Fluctuations in the exchange rate have large influences on wages, interest rates, prices, production levels, and employment. These variables have a large impact on people's everyday life and the standard of living. The exchange rate and its ultimate effects on trade, national income, and welfare of a nation are of importance for policymakers. Economists for a long period of time put emphasize on the relation between exchange rates and the trade balance. Since the middle of the twentieth century, there has been development in macroeconomic analysis that shows results on this issue. For an open economy, the reaction of the exchange rate fluctuations on the trade balance is important to understand because of the possibility to target the trade balance to get the optimal national income. Devaluation under a fixed exchange rate regime is typically expected to eliminate persistent trade balance deficits. A theory that explains this relationship and makes it easier to predict the outcome of devaluation or depreciation of the exchange rate for policymakers is the theory of the J-curve [1]. Choosing an exchange rate regime is one of the most important decisions in macroeconomic policy for developing countries. For instance, countries may select an exchange rate regime that allows them to gain credibility and stabilize monetary aggregates in order to control domestic inflation. On the other hand, primary-commodity exporters may want to implement an exchange rate regime that shields them from volatile external shocks. In any case, adopting a particular exchange rate regime may respond to domestic conditions and to some extent to global conditions faced by the country. The theoretical and empirical literature on the determinants of the exchange rate regime choice is abundant. However, recent reviews of the empirical literature point out that the lack of robustness of the evidence prevents us from making general statements on how countries choose their exchange rate regime. Different trade policies have been implemented by the different governments that have ruled Ethiopia. The policy adopted in the pre-1991/92 period (both in the imperial and military government of Ethiopia) was characterized by strongly inward- oriented development strategy that had a negative impact on export through influencing directly or indirectly the profitability and competitiveness of export. The current government that came to power in 1991/92 has undertaken trade policy reforms, which aimed at promoting exports through diversifying the country's commodity exports. The possible dynamic impact of an export promotion (EP) trade strategy is the ability to import foreign technology. With the growth of exports new technologies that are important for development can be imported. Thus, the overall rate of growth is likely to be increased as the rate of technical innovation increases. For these reasons, advocators of an EP strategy propose a move toward outward oriented policies as best strategies for promoting growth. In this respect, many studies have been made to validate whether an EP trade strategy is a superior policy or not. Most of these studies confirmed that countries

*Corresponding author: Gebeyehu $\mathrm{AB}$, Master of Science in Economic Policy Analysis, Department of Economics, Aksum University, Axum, Ethiopia, Tel: +25134-775-35-89; E-mail: abebebelay22@gmail.com

Received December 26, 2014; Accepted April 29, 2015; Published May 09, 2015

Citation: Gebeyehu AB (2015) Major Agricultural Trade Volume in Ethiopia: Trade Balance and Exchange Rate Relations a Structural Break Analysis (Using Stability Chow Test, CUSUM and CUSUM Squared Residuals). J Glob Econ 3: 138. doi:10.4172/2375-4389.1000138

Copyright: (C) 2015 Gebeyehu AB. This is an open-access article distributed unde the terms of the Creative Commons Attribution License, which permits unrestricted use, distribution, and reproduction in any medium, provided the original author and source are credited. 
that adopted export led trade strategy performed better in terms of growth than those that adopted the import substituting (IS) trade strategy. This led many developing countries to look towards the EP strategy. During the period Pre-1974/75 the foreign trade sector was governed by a relatively free market oriented policies with the private sector (mainly foreign capital) occupying the lion's share in both export and import activities. Although import substitution was the dominant trade strategy of the country, the concern over export diversification, at least explicitly, started with the First Five-Year Development Plan (1957-1961) that acknowledged the economic instability consequences of the dependence on two or three products. The Second Five Year Development Plan (1962-1966) placed great emphasis on structural change and export diversification to achieve higher level of foreign exchange earnings (Imperial Government of Ethiopia, 1962). The plan envisaged to reduce agricultural products export share from $93.6 \%$ in 1961 to $72.3 \%$ in 1966 while that of manufactured products expected to pick-up from 5.2 percent to 24.2 percent during the same period.

In the period 1974/75-1990/91, the export objectives of the ten years perspective plan of the durg regime were increasing foreign exchange earnings, reducing the dependence of the country's export sector on limited export markets, increasing the amount and composition of manufactured exports and increasing the socialization of the export sector (Provisional Military Government of Socialist Ethiopia, 1985).

By emphasizing the role of state owned export companies, geographic diversification of exports towards the markets of socialist countries and neighboring African countries as well as diversification towards manufactured products, to a greater extent, were the agendas of the perspective plan. During the plan period, average annual export growth rate of 15.4 was targeted and state export companies were expected to play a critical role by occupying 90 percent of the export business.

The economic policy of the Transitional Government of Ethiopia during Post- 1990/91 acknowledged the importance of increasing and diversifying the country's exports to ease foreign currency shortages along a free market-based economic path (Transitional Government of Ethiopia, 1991). By minimizing the role of the state in foreign trade sector and by ensuring adequate private capital participation in the export business, the government aimed at increasing exports and foreign exchange earnings. To this end, measures such as provision of fiscal incentives to exporters, the replacement of quantitative restrictions with tariffs, encouraging export-oriented investment, minimizing administrative and bureaucratic procedures and promotion of the use of trade information were highlighted. Export licensing procedures were streamlined and the bureaucratic trade licensing chains were practically abandoned. The Birr was devalued and the foreign exchange market was step-by-step liberalized. With the view of enhancing export competitiveness all taxes on exports (except coffee) and subsidies to parastatal exporting enterprises were abolished as of December 1992 and as of April 2001. An Export Trade Duty Incentives Scheme was introduced. A legal base was created for the registration of external loan and suppliers' or foreign partners' credit.

The J-Curve is a term used to describe the post-devaluation behavior of the trade balance, i.e., initial deterioration followed by an improvement. Previous research has tested the phenomenon for many developed and developing countries. However, African nations have not received any attention on this regard. Glenville Rawlins and John Praveen have done an econometric analysis of annual data for nineteen Sub-Sahara African countries was carried out. They were: Burkina Faso, Cameroon, Central African Republic, Côted'Ivoire, Gabon, The Gambia, Ghana, Kenya, Madagascar, Mauritius, Niger, Nigeria,
Rwanda, Senegal, Sierra Leone, Tanzania, Togo, Zaire, and Zambia. There was overwhelming evidence (seventeen of nineteen countries) that real exchange rate depreciation did improve a country's trade balance in the year of the devaluation. The devaluation's influence on the trade balance carried forward to subsequent years although this did not always indicate a continuing improvement. For two countries there was some indication of a $J$ curve, in that for the first year after the devaluation, the real exchange rate was helping to worsen the trade balance, whereas in the two subsequent years it worked to improve the trade balance. However as measured by the level of significance of the " $T$ " statistics, the evidence is sufficiently compelling only in the case of Tanzania.

Mohsen Bahmani-Oskooee and Abera Gelan had test the hypothesis of $\mathrm{J}$ curve for nine African countries of Burundi, Egypt, Kenya, Mauritius, Morocco, Nigeria, Sierra Leone, South Africa, and Tanzania for which quarterly trade data were available. After using the bounds testing approach to cointegration and error-correction modeling, they were unable to find any support for the J-Curve.

The J curve has not been observed in many African countries; hence there is little reason to expect it in Ethiopia. Theoretically, the J-curve effect holds true only if a country has a balanced BOP position at the time of devaluation, which is not the case in Ethiopia. So, for Ethiopia, the J-curve effect cannot be expected to hold true. Hence the researcher expects the non-existence of J curve in Ethiopia.

Any policy has its own merits and demerits what matters is whether the benefit from the policy implementation outweigh the cost (its disadvantages). One can conceptualize the conflicting and complementary objectives in our macroeconomic policy lesson here. This case is not different for the devaluation policy.

Higher level of exports which is resulted from devaluation of currency should lead to an improvement in the current account deficit. Of course there are a lot of both theoretical and empirical evidence for that. Higher exports and aggregate demand can lead to higher rates of economic growth. Economic growth (GDP) higher exports (an injection into the circular flow) and falling imports leads to rising GDP levels. Growth because of increased money supply devaluation will lead to an increased money supply in an economy, which in turn will increase aggregate consumption, demand, saving and investment. All these increments will lead to some amount of growth in an economy. Reduced imports resulted from devaluation measure leads to increase in the demand for domestic goods. This increases the domestic supply of goods in an economy and which in turn increases economic activities that require more manpower; leading to increasing employment rates and reducing unemployment rates. Devaluation is likely to cause inflation. Devaluation of a currency can hamper the creditworthiness of an economy in the global market; making it very unreliable. Devaluation of a currency makes the investors very skeptical about the economy's future prospects; hence there is way to capital flight. Other factors being equal, an improvement in country's trade balance means a decrease in the trade balance somewhere else in the world, since the sum of all world trade balances must equal zero. By logic of this argument, an improvement in one country's trade balance must be gained at the expense of its trading partners' trade balances. This is why devaluation is often referred to as a "beggar-thy-neighbor" policy. One also can mention what we call "Domino Effect": If one nation has devalued its currency, other neighboring nations can take it as a threat; as foreigners will be more attracted to an economy which has devalued its currency. Looking at this scenario the other countries can also devalue its currency. Thus devaluation may not achieve its target. 
The traditional argument for export diversification is based on its role in reducing export earnings instability caused by cyclical fluctuation in international commodity prices. The notion of commodity concentration and the inability to offset the fluctuation in the principal commodity exports by counter fluctuations and/or stability in the export of others has been at the center of the argument. Wilson argued "when economies are dependent on just one export commodity, their foreign exchange position is frequently precarious." According to Massel concentration on a narrow range of export products is the source of fluctuations in export earnings. He quoted Ghana and Sudan as examples of "one crop economies" dependent on cocoa, and cotton, respectively and argued for diversification to achieve greater degree of earnings stability. In a similar line of reasoning Loveargued: "The more highly concentrated a country's exports, the lower is the probability that fluctuations in one direction in some of its exports will be offset by counter fluctuations or stability in others. Hence, the need for diversification which has tended to be equated with the expansion of manufactured exports."

The new argument on the demand side is that exporters facing autonomous factors such as rising income and change in taste in importing countries have to diversify their exports towards incomeelastic ones. The supply side argument is in terms of production structure adjustment to changes in production technology and input mix, better land utilization, the introduction of new skills, changes in the availability of imported inputs, in response to potential competitors, etc. The proposal is to diversify in to products with different price elasticity of supply thereby minimizing the risk of export earnings instability. A related but important consideration in the literature is the positive relationship between export diversification and industrial capability. Since industrial capability enables product differentiation, a country can offer new products to the world market by varying packaging and label. Moreover, industrial production increases the competitiveness of export products by lowering unit costs. Environmental considerations especially the preference of many developed countries towards organically grown agricultural products, encourage commodity exporting countries to diversify in to new organically grown products. Diversification is also justifiable on account of increased debt problem in many least developed countries.

The concept of the J-Curve phenomenon was introduced into the literature by Magee (1973) who observed deterioration in the U.S. trade balance despite devaluation of the dollar by $15 \%$ in 1971 . BahmaniOskooee then introduced a simple reduced form model of the trade balance in which the trade balance was related to the real exchange rate in addition to other variables.

In general there have been 3 types of approaches towards the J curve estimation. First, Bahmani-Oskooee proposed a trade balance model using the Almon lag structure which employed aggregate trade data. A second stream was initiated by Rose and Yellen [2] which argued that using aggregate data in J cure analyses created the so called "aggregate bias". Therefore it was proposed to conduct a bilateral analysis. A third major direction in the $J$ curve sphere of research was opened by a pioneering study by Bahmani-oskoooee and Wang who disaggregated the trade data even further to the level of industries and specific trade sectors. We need to note that while some studies have used aggregate trade data, some have employed bilateral trade data. Again, the findings are mixed. In this research paper the researcher used only the first approach of estimating $\mathrm{J}$ curve effect of devaluation: employing an aggregate trade data/multilateral trade model.

Petrovic and Gligoric [3] have done exchange rate and trade balance:
J curve in Serbia. Upon their work the J curve effect of devaluation was found to exist. Both Johansen's and ARDL were used giving similar long run estimates/results showing that real depreciation improves trade balance. Corresponding to short run estimates error correction models as well as impulse response functions were used indicating following depreciation, trade balance deteriorates before it get improved. The paper has used a multilateral trade model with monthly frequencies seasonally adjusted running from January 2002 to September 2007, of course there were data on quarterly basis but using an ecotrim software it was further disaggregated into monthly index. The model included TB model as a function of real effective exchange rate and domestic GDP and foreign income however, upon preliminary testing foreign income is found to be statistically insignificant and thus the model ends up with estimating the model with only Domestic GDP and real effective exchange rate. The long run cointegrating trade balance model showed a one percent real depreciation leads to a 0.92 to 0.95 percent improvement in trade balance. The estimates showed of the real depreciation deteriorate the trade balance only in the first five months of devaluation. Domestic GDP found to have a positive effect on trade balance.

Bahmani-Oskooee and Ali M. Kutanhas investigated the J curve in the emerging economies of eastern Europe they used a monthly data over the January 1990 to June 2005 period for 11 east European emerging economies most of which are the new European union member (EU) or candidates. Bulgaria, Croatia, Cyprus, the Czech Republic, Hungary, Poland, Romania, Russia, Slovakia, Turkey, and Ukraine. Sample countries were chosen based on data availability nothing more. The coverage period differed among the countries. Monthly data over the January 1990 - June 2005 were used for Cyprus, Hungary, Poland and Turkey. For Romania the study period was January 1991 - June 2005. For Croatia, the period was January 1992 - June 2005. For Czech Republic and Slovakia the period was January 1993- June 2005. For Russia and Ukraine it was January 1994-June 2005. Finally, for Bulgaria the period of analysis was January 1995 - June 2004. The methodology was based on the bounds testing approach to co-integration and error correction modeling which does not require pre-unit root testing. Using the bound testing/ARDL approach they have got an empirical support for J curve effect of devaluation for countries: Bulgaria, Crotia and Russia While in many of the countries real depreciation had shortrun effect, the short-run effects did not last into the long run thus these countries are not advised to use exchange rate policy as an engine to promote trade balance rather other channels like fiscal, monetary policy shall be used. What benefits these countries is avoiding exchange rate fluctuation if not possible, reduce it.

\section{Data Results and Discussion}

\section{Export and import volume in some major agricultural products in Ethiopia}

As an agrarian economy it is little to expect for one nation to import more agricultural products than it exports. However, the everincreasing total trade deficit in Ethiopia comes from both agricultural and industrial sector. The country reported a huge individual trade deficit in some agricultural product where it has potential to narrow the ever increasing aggregate trade deficit. The country had recorded a huge trade volume deficit in some major agricultural products like soya bean, Malt Not Roasted, Spelt, common Wheat and Meslin, Durum Wheat, Grain Sorghum, Dried Peas, Shelled And Wheat/Meslin Flour.

This huge difference could also be reflected through the value measure. In both value and volume measures it seems as there is no promising figure to close such difference (Tables 1-7). 
Citation: Gebeyehu AB (2015) Major Agricultural Trade Volume in Ethiopia: Trade Balance and Exchange Rate Relations a Structural Break Analysis (Using Stability Chow Test, CUSUM and CUSUM Squared Residuals). J Glob Econ 3: 138. doi:10.4172/2375-4389.1000138

Page 4 of 10

\section{Unit root test and the time series properties of main variables}

To be able to establish possible existence of co-integration link, the benchmark augmented Dickey-Fuller (ADF) unit root tests was performed to check the order of integration of trade balance, real effective exchange rate index, domestic GDP and world industrial production index. The results obtained are reported below in this section. Based on the ADF test statistic(s), it was found that all variables are I (1) Even though the ARDL framework does not require the pretesting of variables, the unit root test could help in determining whether or not the ARDL model should be used. If for instance, I (2) variable/s is/are found, ARDL not applicable (Figure 1).

\section{Graphical illustration and unit root test based on ADF}

Since the computed ADF test-statistics (-1.478375) is greater than

\begin{tabular}{|c|c|c|c|}
\hline Year & Import & Export & $\begin{array}{c}\text { Volume } \\
\text { Difference }\end{array}$ \\
\hline 2002 & 0 & 181,667 & 181,667 \\
\hline 2003 & 2 & 70568 & 70,566 \\
\hline 2004 & 597078 & $1,639,910$ & $1,042,832$ \\
\hline 2005 & 2953147 & 0 & $-2,953,147$ \\
\hline 2006 & 7523366 & 5880 & $-7,517,486$ \\
\hline 2007 & 117661 & $2,195,905$ & $2,078,244$ \\
\hline 2008 & 573904 & $2,120,907$ & $1,547,003$ \\
\hline 2009 & 6569770 & 462,010 & $-6,107,760$ \\
\hline 2010 & 512495 & 357,284 & $-155,211$ \\
\hline 2011 & 1405646 & $1,004,496$ & $-401,150$ \\
\hline 2012 & 363567 & $4,221,000$ & $3,857,433$ \\
\hline
\end{tabular}

Source: CSA (Central Statistical Agency)

Table 1: Volume of Export and import in soya bean in $\mathrm{Kg} \mathrm{(2002-2012).}$

\begin{tabular}{|c|c|c|c|}
\hline Year & Import & Export & Volume Difference \\
\hline 2002 & 5509000 & 1,466 & $-5,507,534$ \\
\hline 2003 & 5425000 & 50 & $-5,424,950$ \\
\hline 2004 & 5847301 & 0 & $-5,847,301$ \\
\hline 2005 & 10913241 & 0 & $-10,913,241$ \\
\hline 2006 & 27120186 & 0 & $-27,120,186$ \\
\hline 2007 & 32183670 & 2,229 & $-32,181,441$ \\
\hline 2008 & 30296967 & 5232 & $-30,291,735$ \\
\hline 2009 & 21724178 & 2,060 & $-21,722,118$ \\
\hline 2010 & 32891810 & 4,093 & $-32,887,717$ \\
\hline 2011 & 26678048 & 7,510 & $-26,670,538$ \\
\hline 2012 & 26470743 & 5,571 & $-26,465,172$ \\
\hline
\end{tabular}

Source: CSA

Table 2: Export and import Volumes (in Kg) of Malt not roasted in 2002-2012.

\begin{tabular}{|c|c|c|c|}
\hline Year & Import & Export & $\begin{array}{c}\text { Volume } \\
\text { Difference }\end{array}$ \\
\hline 2002 & $212,434,363$ & 3,196 & $212,434,363$ \\
\hline 2003 & $727,155,602$ & 8,889 & $727,155,602$ \\
\hline 2004 & $162,086,291$ & 15,167 & $162,086,291$ \\
\hline 2005 & $131,606,121$ & 0 & $131,606,121$ \\
\hline 2006 & $148,555,221$ & 0 & $148,555,221$ \\
\hline 2007 & $185,239,108$ & 184 & $185,239,108$ \\
\hline 2008 & $281,672,943$ & 16,012 & $281,672,943$ \\
\hline 2009 & $307,750,797$ & 507 & $307,750,797$ \\
\hline 2010 & $161,648,887$ & 5,000 & $161,648,887$ \\
\hline 2011 & $476,291,674$ & 400,000 & $476,291,674$ \\
\hline 2012 & $518,799,049$ & $10,231,120$ & $518,799,049$ \\
\hline
\end{tabular}

Table 3: Export and import volumes (in $\mathrm{kg}$ ) of Spelt, common wheat and meslin.

\begin{tabular}{|c|c|c|c|}
\hline Year & Import & Export & Volume Difference \\
\hline 2002 & $214,751,551$ & 90,835 & $-214,660,716$ \\
\hline 2003 & $875,947,444$ & 49,253 & $-875,898,191$ \\
\hline 2004 & $412,934,048$ & 38,480 & $-412,895,568$ \\
\hline 2005 & $730,539,401$ & 0 & $-730,539,401$ \\
\hline 2006 & $219,020,726$ & 0 & $-219,020,726$ \\
\hline 2007 & $198,888,407$ & 759 & $-198,887,648$ \\
\hline 2008 & $818,377,229$ & 19,200 & $-818,358,029$ \\
\hline 2009 & $803,771,368$ & 0 & $-803,771,368$ \\
\hline 2010 & $887,057,532$ & 0 & $-887,057,532$ \\
\hline 2011 & $602,010,670$ & $1,360,000$ & $-600,650,670$ \\
\hline 2012 & $511,959,297$ & 50,400 & $-511,908,897$ \\
\hline
\end{tabular}

Table 4: Export and import volume (in kg) of Durum wheat in 2002-2012.

\begin{tabular}{|c|c|c|c|}
\hline Year & Import & Export & Volume Difference \\
\hline 2002 & 5 & $1,198,246$ & $1,198,241$ \\
\hline 2003 & 246,741 & $1,411,793$ & $1,165,052$ \\
\hline 2004 & $4,605,750$ & $1,760,485$ & $-2,845,265$ \\
\hline 2005 & 0 & 0 & 0 \\
\hline 2006 & 0 & 120,000 & 120,000 \\
\hline 2007 & 0 & $3,175,608$ & $3,175,608$ \\
\hline 2008 & $252,697,371$ & $3,755,173$ & $-248,942,198$ \\
\hline 2009 & $69,770,412$ & 0 & $-69,770,412$ \\
\hline 2010 & $113,260,000$ & $33,501,440$ & $-79,758,560$ \\
\hline 2011 & $33,790,089$ & $31,378,219$ & $-2,411,870$ \\
\hline 2012 & $25,845,900$ & $14,947,331$ & $-10,898,569$ \\
\hline
\end{tabular}

Source: CSA

Table 5: Export and import volume (in kg) of Grain sorghum in 2002-2012.

\begin{tabular}{|c|c|c|c|}
\hline Year & Import & Export & Volume Difference \\
\hline 2002 & 0 & 11,711 & 11,711 \\
\hline 2003 & 207,832 & 55,976 & $-151,856$ \\
\hline 2004 & $3,811,007$ & 271,971 & $-3,539,036$ \\
\hline 2005 & $8,864,505$ & 0 & $-8,864,505$ \\
\hline 2006 & $15,127,313$ & 62,874 & $-15,064,439$ \\
\hline 2007 & $26,428,716$ & $2,842,509$ & $-23,586,207$ \\
\hline 2008 & $22,402,464$ & $1,697,910$ & $-20,704,554$ \\
\hline 2009 & $32,255,262$ & $1,162,969$ & $-31,092,293$ \\
\hline 2010 & $38,653,023$ & 415,543 & $-38,237,480$ \\
\hline 2011 & $38,359,783$ & 455,907 & $-37,903,876$ \\
\hline 2012 & $25,592,998$ & 427,005 & $-25,165,993$ \\
\hline
\end{tabular}

Table 6: Export and import volume (in birr) of Dried peas,shelled 2002-2012.

\begin{tabular}{|c|c|c|c|}
\hline Year & Import & Export & Volume Difference \\
\hline 2002 & $11,543,838$ & 0 & $-11,543,838$ \\
\hline 2003 & $48,765,320$ & 700 & $-48,764,620$ \\
\hline 2004 & 824,868 & 30,505 & $-794,363$ \\
\hline 2005 & 88,716 & 0 & $-88,716$ \\
\hline 2006 & $1,309,409$ & 0 & $-1,309,409$ \\
\hline 2007 & 957,292 & 220,625 & -736667 \\
\hline 2008 & $6,061,986$ & 1015 & $-6,060,971$ \\
\hline 2009 & $99,970,669$ & 559 & $-99,970,110$ \\
\hline 2010 & $7,029,886$ & 250 & $-7,029,636$ \\
\hline 2011 & $45,612,604$ & 2,549 & $-45,610,055$ \\
\hline 2012 & $23,429,446$ & 11,275 & $-23,418,171$ \\
\hline
\end{tabular}

Table 7: Export and import volume (in birr) of wheat flour in 2002-2012.

the critical values --"tau"(-3.6228, -2.9446 and -2.6105 at $1 \%, 5 \%$ and $10 \%$ significant level, respectively), we cannot reject Ho. That means the LREER series has a unit root problem and the LREER series is a nonstationary series. Test of stationary basically is done in order to identify 
Citation: Gebeyehu AB (2015) Major Agricultural Trade Volume in Ethiopia: Trade Balance and Exchange Rate Relations a Structural Break Analysis (Using Stability Chow Test, CUSUM and CUSUM Squared Residuals). J Glob Econ 3: 138. doi:10.4172/2375-4389.1000138

the order of integration (Figure 2). Hence since LREER at level is non -stationary we will continue first differencing until the LREER has got stationary property based on ADF. Graphically the first difference of LREER (DLREER) looks stationary but it is up to the ADF test below (Table 8).

Here the computed ADF test-statistics -3.915675 is less than the critical values --"tau"(-3.6289, -2.9472 and -2.6118 at $1 \%, 5 \%$ and $10 \%$ significant level, respectively). That means the DLREER series has no a unit root problem and the DLREER series is a stationary series. LREER is I (I) variable (Table 9).

Here the computed ADF test-statistics -0.058190 is more than the critical values --"tau"(-3.6228, -2.9446 and -2.6105 at $1 \%, 5 \%$ and $10 \%$ significant level, respectively). That means the LTB series has a unit root problem and the LTB series is a non stationary series (Figure 3). Of course the graphically illustration above confirm this. BUT its first difference not (Table 10).

Since the computed ADF test-statistics -5.482377is less than the critical values --"tau"(-3.6289, -2.9472 and -2.6118 at $1 \%, 5 \%$ and $10 \%$ significant level, respectively) (Figure 4). That means the DLTB series has no a unit root problem and the DLTB series is a stationary series. LTB is I (I) variable (Table 11).

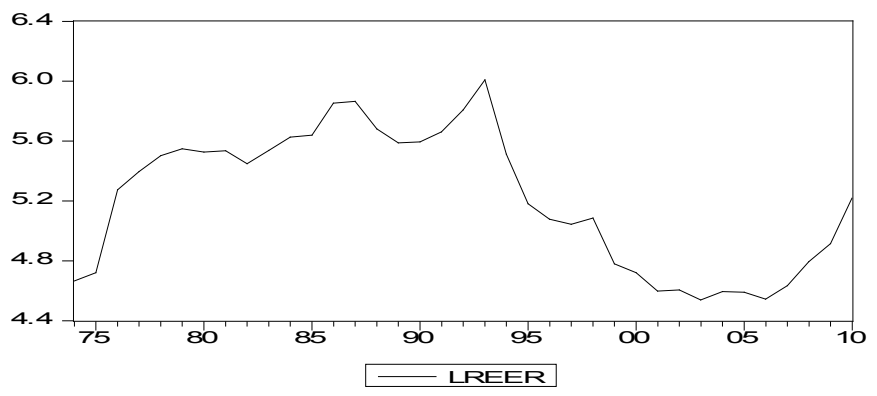

Figure 1: Time series property of LREER.

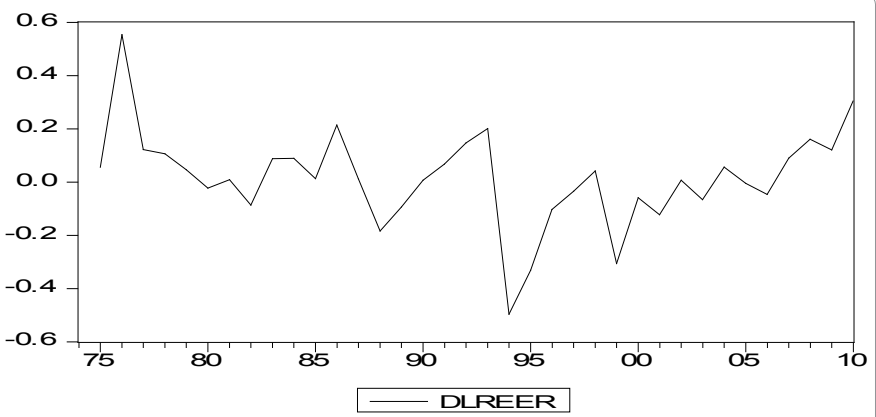

Figure 2: Time series property of DLREER.

\begin{tabular}{|l|l|ll|l|}
\hline ADF Test Statistic & -1.478375 & $1 \%$ & Critical Value & -3.6228 \\
\hline & & $5 \%$ & Critical Value & -2.9446 \\
\hline & & $10 \%$ Critical Value & -2.6105 \\
\hline
\end{tabular}

MacKinnon critical values for rejection of hypothesis of a unit root.

Table 8: Unit root test for LREER.

\begin{tabular}{|l|r|r|r|r|}
\hline ADF Test Statistic & -3.915675 & $1 \%$ & Critical Value & -3.6289 \\
\hline & & $5 \%$ & Critical Value & -2.9472 \\
\hline & $10 \%$ Critical Value & -2.6118 \\
\hline \multicolumn{2}{|l|}{ MacKinnon critical values for rejection of hypothesis of a unit root. } \\
\hline
\end{tabular}

Table 9: Unit root test for DLREER.

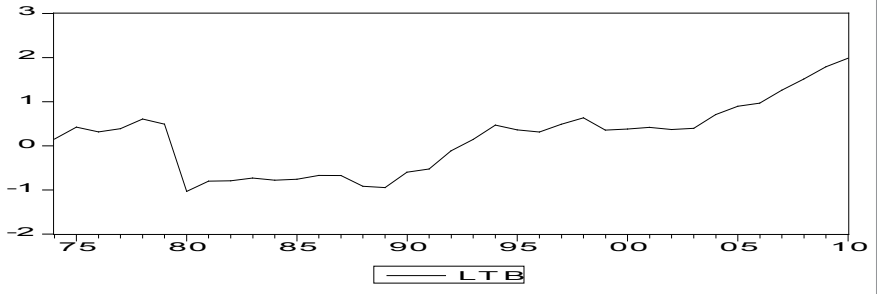

Figure 3: Time series property of LTB.

\begin{tabular}{|l|l|l|l|}
\hline ADF Test Statistic & -0.058190 & $1 \%$ Critical Value & -3.6228 \\
\hline & & $5 \%$ Critical Value & -2.9446 \\
\hline & & $10 \%$ Critical Value & -2.6105 \\
\hline
\end{tabular}

MacKinnon critical values for rejection of hypothesis of a unit root.

Table 10: Unit root test for LTB .

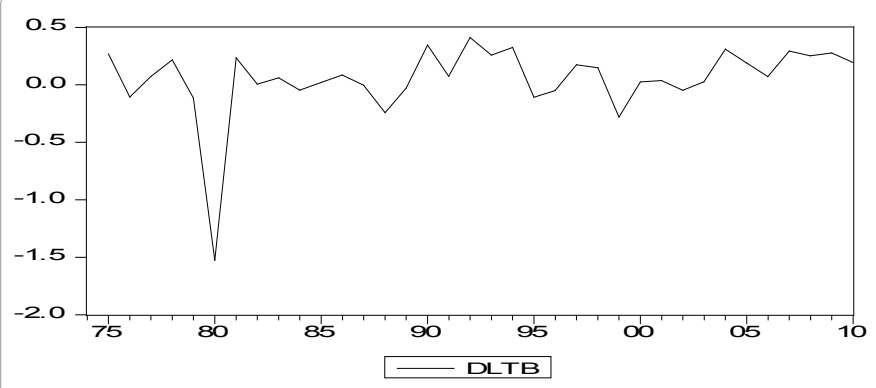

Figure 4: Time series property of DLTB.

\begin{tabular}{|c|c|c|c|}
\hline ADF Test Statistic & -5.482377 & $1 \%$ Critical Value & -3.6289 \\
\hline & & $5 \%$ Critical Value & -2.9472 \\
\hline & & $10 \%$ Critical Value & -2.6118 \\
\hline
\end{tabular}

Table 11: Unit root test for DLTB.

\begin{tabular}{|l|l|ll|r|}
\hline ADF Test Statistic & -1.133569 & $1 \%$ & Critical Value & -3.6228 \\
\hline & & $5 \%$ & Critical Value & -2.9446 \\
\hline & & $10 \%$ Critical Value & -2.6105 \\
\hline
\end{tabular}

MacKinnon critical values for rejection of hypothesis of a unit root.

Table 12: Unit root test for LIPI.

The series seems as a non-stationary data since it is increased upward as time changes. The (Table 12) result below confirm this based on ADF (Figure 5).

Since ADF test statistic more than all critical values, the LIPI is non-stationary (Table 13).

However the result above confirm that LIPI is stationary after first differenced, in all $1 \%, 5 \%$ and $10 \%$ significance level hence it is $\mathrm{I}(1)$ variable, as the ADF test statistic less than critical values (Table 13 and Figure 6).

LRGDP is non -stationary as ADF test statistic result is more than critical values. However it takes stationary property when we make it first difference. The result of unit root test for first difference in LRGDP based on ADF is given below with graphically (Table 14 and Figure 7).

However both the graphical illustration and the ADF results confirm LRGDP is I (1) (Figure 8 and Table 15). 


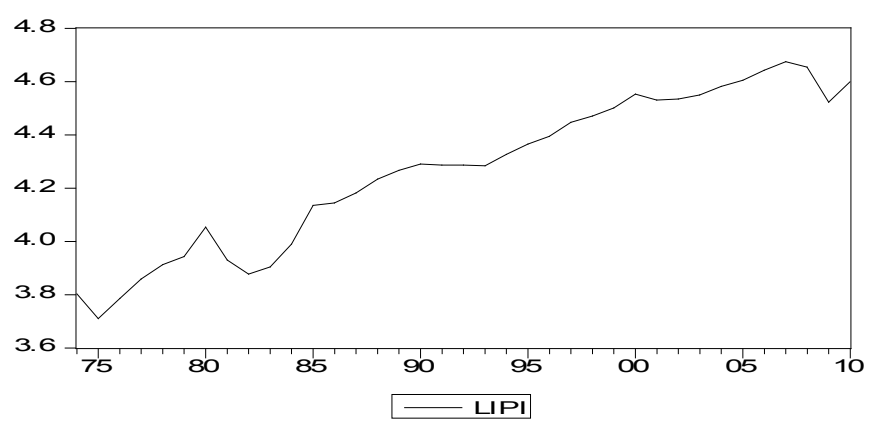

Figure 5: Time series property of LIPI.

\begin{tabular}{|l|l|ll|l|}
\hline ADF Test Statistic & -5.861799 & $1 \%$ & Critical Value & -3.6289 \\
\hline & & $5 \%$ & Critical Value & -2.9472 \\
\hline & & $10 \%$ & Critical Value & -2.6118 \\
\hline
\end{tabular}

MacKinnon critical values for rejection of hypothesis of a unit root.

Table 13: Unit root test for DLIPI.

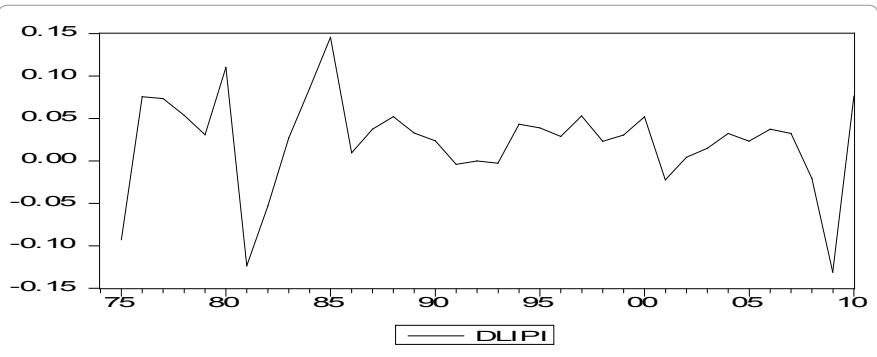

Figure 6: Time series property of DLIPI.

\section{A. Stability test result}

Here the null hypothesis is H0: no structural break just looks at p-value of $\mathrm{f}$-statistics it is 0.0016 which is below $5 \%$ So reject $\mathrm{H} 0$ and there is structural break in data (Table 16).

\section{CUSUM stability test}

The CUSUM is between critical value lines hence the regression model is stable (Figure 9).

\section{CUSUM square}

The movement of the CUSUM and CUSUM squared residuals observations which were updated recursively and plotted against break points fall within the critical lines as shown in (Figures 9- 10). Therefore, the reasracher posit that inspite the earlier shift from fixed exchange rate system to a managed float exchange rate system that could have affected the variables in our model, the null hypothesis of parameter stability cannot be rejected at the $5 \%$ significance level. Hence, thus there absence of structural breaks.

\section{Normality test}

The residual is normally distributed as $\mathrm{P}>0.05 ; 0.484457>0.005$ (Figure 11).

\section{Serial correlation LM test}

Since the obs ${ }^{\star} R$-squared probability value $(0.985832)$ more than 0.05 , there is no serial correlation. The Breusch-Godfrey LM test indicates statistical independence of the regressors and the regression disturbance. This is reinforced by a D-W statistic which hovers around 2 (Table 17).

\section{Impulse response function (IRFs)}

The short run effect of devaluation can be captured by the impulse response graph indicated below.

Impulse response enables one to track the evolution of the trade

\begin{tabular}{|l|l|ll|r|}
\hline ADF Test Statistic & 2.120091 & $1 \%$ & Critical Value & -3.6228 \\
\hline & & $5 \%$ & Critical Value & -2.9446 \\
\hline & & $10 \%$ Critical Value & -2.6105 \\
\hline
\end{tabular}

MacKinnon critical values for rejection of hypothesis of a unit root.

Table 14: Unit root test for LRGDP.

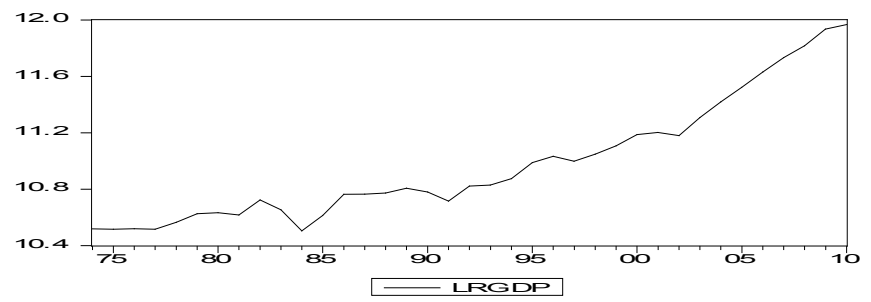

Figure 7: Time series property of LRGDP.

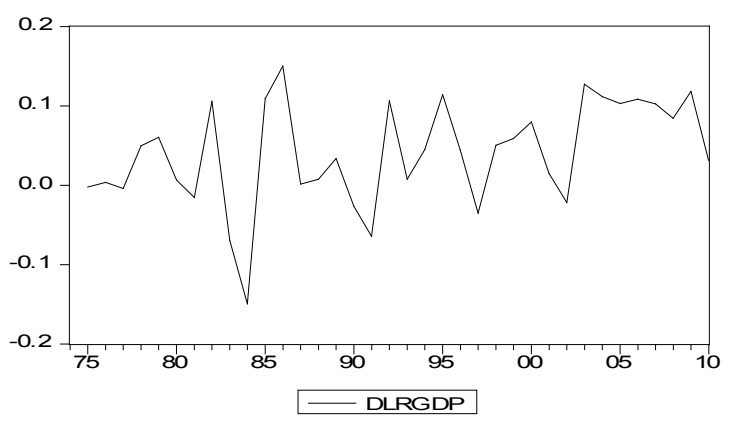

Figure 8: Time series property of DLRGDP.

\begin{tabular}{|l|l|r|r|r|}
\hline ADF Test Statistic & 2.120091 & $1 \%$ & Critical Value & -3.6228 \\
\hline & & $5 \%$ & Critical Value & -2.9446 \\
\hline & & $10 \%$ Critical Value & -2.6105 \\
\hline
\end{tabular}

Table 15: Unit root test for DLRGDP.

Chow Breakpoint Test: 1991

\begin{tabular}{|l|c|c|c|}
\hline F-statistic & 1.952532 & Probability & 0.143806 \\
\hline Log likelihood ratio & 31.64050 & Probability & 0.000460 \\
\hline
\end{tabular}

Table 16: Stability chow test.

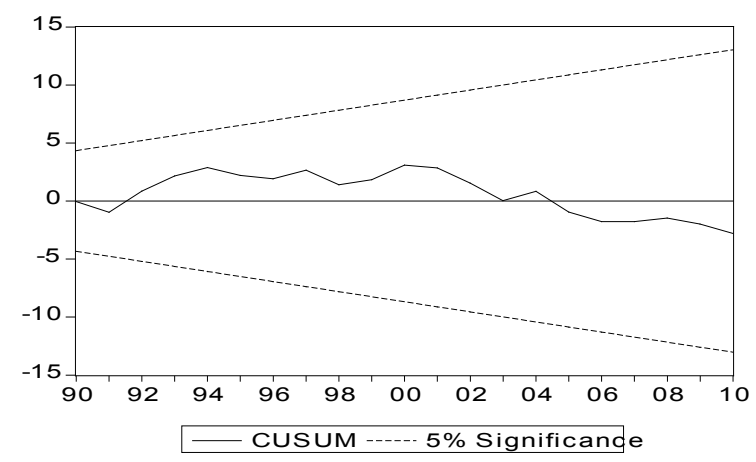

Figure 9: CUSUM stability test. 


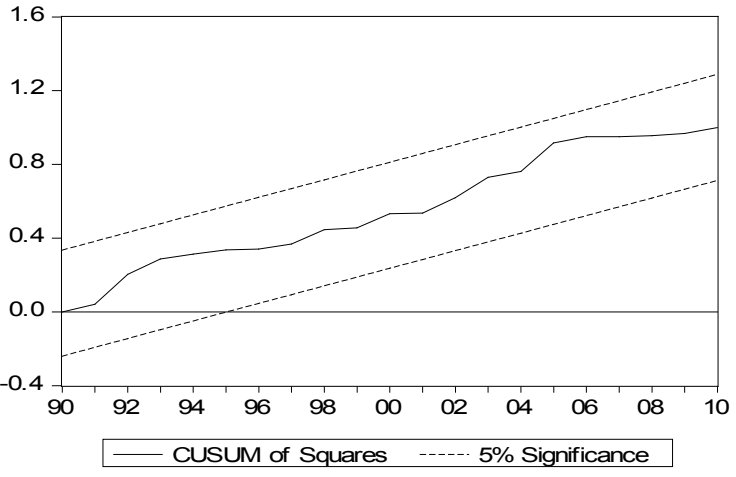

Figure 10: CUSUM squared residuals observations.

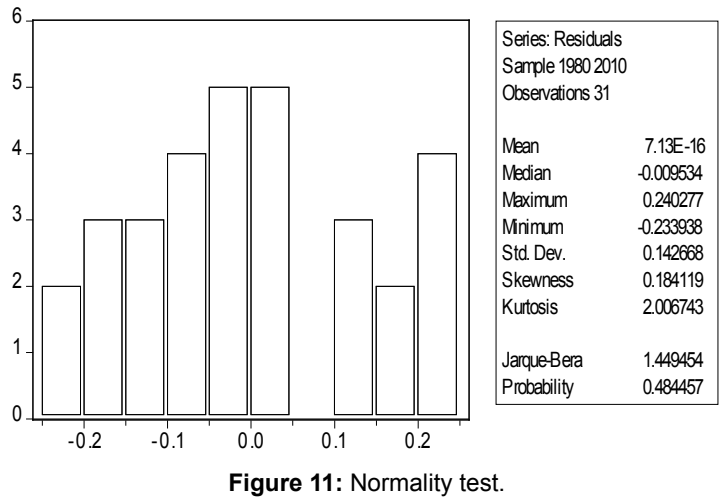

\begin{tabular}{c|c|c|r} 
F-statistic & 0.008754 & Probability & 0.991288 \\
\hline Obs ${ }^{*}$ R-squared & 0.028539 & Probability & 0.985832 \\
\hline
\end{tabular}

Table 17: Breusch-Godfrey Serial Correlation LM Test:

\begin{tabular}{|c|c|}
\hline Period & \\
\hline 1 & $0.000000(0.00000)$ \\
\hline 2 & $-0.042719(0.04398)$ \\
\hline 3 & $-0.015616(0.04847)$ \\
\hline 4 & $0.016016(0.05099)$ \\
\hline 5 & $0.038117(0.05259)$ \\
\hline 6 & $0.048471(0.05031)$ \\
\hline 8 & $0.050781(0.04548)$ \\
\hline 9 & $0.049333(0.04154)$ \\
\hline 10 & $0.047110(0.04008)$ \\
\hline
\end{tabular}

Table 18: Impulse Response of Trade Balance Following Exchange Rate Shock: Effect of One S.D LREER innovation on LTRB.

Response of LTRB to One S.D. LREER Innovation

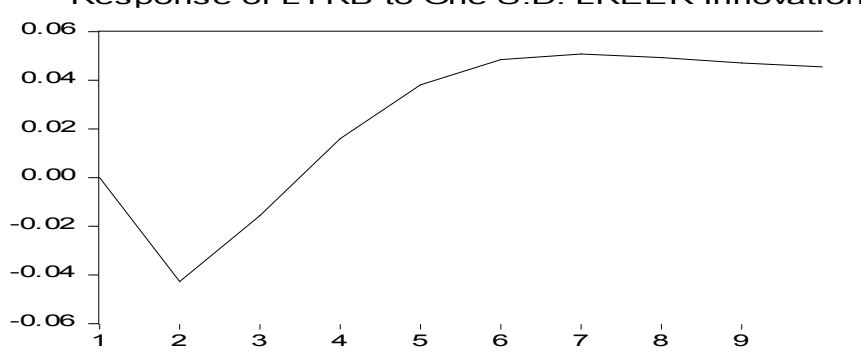

Figure 12: Evolution of Trade Balance Following Real Currency Depreciation: J-curve in Ethiopia (based on unrestricted VAR).

\begin{tabular}{|c|c|}
\hline Period & \\
\hline 1 & 0.000000 \\
\hline 2 & -0.020121 \\
\hline 3 & -0.011405 \\
\hline 4 & 0.015631 \\
\hline 5 & 0.055647 \\
\hline 6 & 0.075118 \\
\hline 7 & 0.083954 \\
\hline 9 & 0.102753 \\
\hline 10 & 0.124091 \\
\hline Ordering: LTRB LREERLIPI LRGDP & 0.143074 \\
\hline
\end{tabular}

Table 19: Impulse Response of Trade Balance Following Exchange Rate Shock.

Response of LTRB to One S.D. LREER Innovation

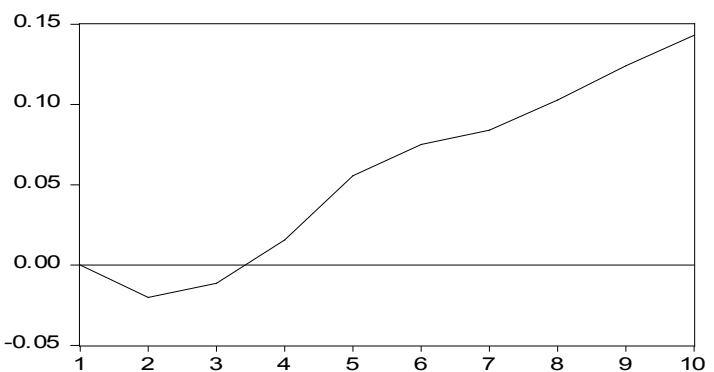

Figure 13: Evolution of Trade Balance Following Real Currency Depreciation: J-curve in Ethiopia (based on VECM).

balance over time subsequent to an exchange rate shock, e.g. a real devaluation of the currency. Thus it explicitly gives an estimate of the J-curve, if present, i.e. its shape and the timing. It encompasses both the period in which trade balance deteriorates ('short run'), and the ensuing phase when trade balance improves ('long run'). Below is the impulse response of trade balance following exchange rate shock.

\section{Impulse Response Functions (IRFs) based on unrestricted VAR}

The result of Impulse Response Function (IRFs) based on unrestricted VAR shows upon real depreciation in the first three years trade balance deteriorates ('short run') and subsequently improves (Table 18). The response of trade balance to real exchange arte innovation/change look like letter J-implying trade balance first (in short run) deteriorates then in long run improves as a result of real depreciation of domestic currency birr (Figure 12).

\section{Impulse Response Functions (IRFs) based on Error correction model}

The results given in both (Table 19 and Figure 13) here based on VECM show that trade balance in Ethiopia after real depreciation of currency follows J-curve patter. More importantly the obtained estimates suggest that upon real depreciation in the first three years trade balance deteriorates ('short run') and subsequently improves.

\section{The Forecast Error Variance Decompositions (VDCs)}

The forecast error variance decomposition for each variable reveals the proportion of the movement in this variable due to its own shocks versus the shocks in other variables. Hence, while the IRFs show the direction of the dynamic response of the variables to different innovations, the VDCs provide the magnitude of the response to the 
Citation: Gebeyehu AB (2015) Major Agricultural Trade Volume in Ethiopia: Trade Balance and Exchange Rate Relations a Structural Break Analysis (Using Stability Chow Test, CUSUM and CUSUM Squared Residuals). J Glob Econ 3: 138. doi:10.4172/2375-4389.1000138

Page 8 of 10

shocks. Further information on the linkages between the trade balance and its determinants can be obtained from variance decompositions, which measure the proportion of forecast error variance in a variable that is explained by innovations (impulses) in itself and the other variables. However, since LTB is the target variable, the discussion below focus on analyzing its variance decomposition over a period of 10 years. In other words, variance decompositions give the proportion of the movements in the dependent variables that are due to their 'own' shocks (innovations), versus shocks to the other variables [4] (Table 20).

The variance decomposition of LTB based on VAR reveals that changes in its own shock, LTB is the predominant source of variation in the logarithm of trade balance. The researcher also observed that own series shock of LTB explain most of the forecast error variance of the series in a VAR. The high explanatory power of the innovations in LTB is sustained over the entire forecast horizon. As seen in table above LTB explains $100 \%$ of the forecast error variance for the change LTB in the first year. The percentage decrease considerably to the entire forecast horizon of 10 years. The LRGDP, LREER and LIPI are insignificant variables for the variation of trade balance in the first period. The change in the LREER represents the second source of variation in LTB with a percentage of $1.4 \%$, and $1.28 \%$ in the second and third year forecast horizons respectively. In these periods LRGDP accounts $0.008 \%$ and $0.5 \%$ respectively. While LIPI accounts $0.35 \%$, and $0.5 \%$ respectively in the second and third period. In the forecast period fourth to ninth the second largest variation in LTB comes from LRGDP. In the tenth period, the second and third predominant source of variation in LTB explained by changes in LIPI and LRGDP respectively. The percentage figure of LREER as a source in variation of logarithmic of trade balance showed improvement almost (excluding the third forecast period which showed a decrease trend to the previous period of forecast) in all forecast period. It runs with zero percentage value in the first forecast period to $6 \%$ at end, the tenth forecast period.

Finally, the results also prove the relative ineffectiveness of the industrial production index in affecting trade balance in Ethiopia since LIPI accounts on average for a small percentage of the variation in the LTB sequence (Table 21).

The variance decomposition based on VECM reveal the predominant source of variation in the logarithm of trade balance is its own shock. Its own series shock of LTB explains most of the forecast error variance of the series in a VECM. Up to the five forecast period, the second predominant source of variation in trade balance is industrial production index. The change in the effective exchange rate/ LREER represents the second source of variation in LTB after the six forecast period. In the first forecast period the total variation inn trade balance comes from its own shock. However the share of its own shock show declining from first to $10^{\text {th }}$ forecast period. Industrial production index ineffectiveness in affecting trade balance.

\section{Conclusion}

Impulse response results show that trade balance in Ethiopia after real depreciation of currency follows J-curve patter. More importantly the obtained estimates suggest that upon real depreciation in the first three years trade balance deteriorates ('short run') and subsequently improves. The forecast error variance decomposition for each variable reveals the proportion of the movement in this variable due to its own shocks versus the shocks in other variables. The variance decomposition of trade balance reveals that changes in its own shock, trade balance is the predominant source of variation in the logarithm of trade balance. The result showed own series shock of trade balance explain most of

\begin{tabular}{|c|c|c|c|c|c|}
\hline Period & S.E. & LTB & LREERI & LIPI & LRGDP \\
\hline 1 & 0.271474 & 100.0000 & 0.000000 & 0.000000 & 0.000000 \\
\hline 2 & 0.360347 & 98.22696 & 1.405375 & 0.359119 & 0.008545 \\
\hline 3 & 0.402118 & 97.68773 & 1.279362 & 0.501879 & 0.531026 \\
\hline 4 & 0.422675 & 96.23515 & 1.301527 & 0.639477 & 1.823846 \\
\hline 5 & 0.436771 & 93.68372 & 1.980525 & 0.905778 & 3.429980 \\
\hline 6 & 0.449469 & 90.60999 & 3.033224 & 1.504482 & 4.852300 \\
\hline 7 & 0.462338 & 87.39825 & 4.073119 & 2.634023 & 5.894605 \\
\hline 8 & 0.476037 & 84.13818 & 4.916067 & 4.359847 & 6.585907 \\
\hline 9 & 0.490759 & 80.83307 & 5.547042 & 6.587947 & 7.031942 \\
\hline 10 & 0.506372 & 77.50547 & 6.017836 & 9.143025 & 7.333670 \\
\hline
\end{tabular}

Table 20: Variance decomposition of LTB (based on VAR).

\begin{tabular}{|c|c|c|c|c|c|}
\hline Period & S.E. & LTB & LREERI & LIPI & LRGDP \\
\hline 1 & 0.292107 & 100.0000 & 0.000000 & 0.000000 & 0.000000 \\
\hline 2 & 0.405280 & 99.27580 & 0.246486 & 0.466791 & 0.010918 \\
\hline 3 & 0.472272 & 99.18416 & 0.239841 & 0.386811 & 0.189192 \\
\hline 4 & 0.527226 & 98.75039 & 0.280332 & 0.809938 & 0.159343 \\
\hline 5 & 0.574319 & 96.96934 & 1.175031 & 1.238241 & 0.617384 \\
\hline 6 & 0.615197 & 95.01080 & 2.514915 & 1.288885 & 1.185399 \\
\hline 7 & 0.654322 & 93.12491 & 3.869335 & 1.183420 & 1.822340 \\
\hline 8 & 0.697153 & 90.52961 & 5.580785 & 1.096086 & 2.793523 \\
\hline 9 & 0.742069 & 87.20280 & 7.721922 & 1.042555 & 4.032725 \\
\hline 10 & 0.786693 & 83.39473 & 10.17821 & 0.984486 & 5.442575 \\
\hline \multicolumn{5}{|c|}{ Table 21: Variance decomposition of LTB (based on VECM). } \\
\hline
\end{tabular}

the forecast error variance of the series in both based on VAR and VECM. Finally, the results also prove the relative ineffectiveness of the industrial production index in affecting trade balance in Ethiopia based on both in VAR and VECM.

\section{Appendix}

\section{Appendix 1}

\section{Methodology for REER in Ethiopia}

If the interest is on the competitive position of the country with its major trading partners, a trade weighted or multilateral real exchang rate will be of relevance. Suppose the birr has depreciated against the US dollar, in other words, the price of dollars has risen. Does it mean that the international value of the birr has fallen? Or would it be accurate to say that the international value of the dollar has risen? From a purely bilateral view, the two amount to the same thing. However, a bilateral perspective is, for many purposes, far too narrow or inadequate The effective or trade weighted exchange rate measures changes in the price of foreign currencies in general by looking at an index of a currency's international value. Weighted multilateral exchange rate indices have been devised to measure, for each country, the average change in the value of its currency in relation to all other currencies, but usually those of its major trading partners. As country's currency can be compared with any other currency and a given country's currency can be expected to appreciate compared some currencies while expected to depreciate against some other currency. But can we generalize, whether a given country currency is expected to appreciate or depreciate? This can be done so by comparing the currency value of any country with the currency value of its major trading partners. Since countries trade with many other countries, to determine the relative purchasing power of a given currency, it needs to be evaluated against all other currency values so that the currency's true value can be identified. In other words, whether a currency is "over-valued" or "under-valued" compared to its major trading partners needs to be determined. This is done by calculating exchange rate indices. These indices are calculated 
Citation: Gebeyehu AB (2015) Major Agricultural Trade Volume in Ethiopia: Trade Balance and Exchange Rate Relations a Structural Break Analysis (Using Stability Chow Test, CUSUM and CUSUM Squared Residuals). J Glob Econ 3: 138. doi:10.4172/2375-4389.1000138

Page 9 of 10

\begin{tabular}{|c|c|}
\hline S. No & Country Name \\
\hline 1 & Belgium \\
\hline 2 & France \\
\hline 3 & Italy \\
\hline 4 & Germany \\
\hline 5 & Netherlands \\
\hline 6 & Sweden \\
\hline 7 & Switzerland \\
\hline 8 & Turkey \\
\hline 9 & UK \\
\hline 10 & US \\
\hline 11 & India \\
\hline 12 & Japan \\
\hline 13 & Korea \\
\hline 15 & Israel \\
\hline 16 & Saudi Arabia \\
\hline 17 & Egypt \\
\hline 18 & Sudan \\
\hline & \\
\hline & \\
\hline
\end{tabular}

Table 22: REERI calculation of 18 countries.

\begin{tabular}{|c|c|c|c|c|c|c|c|}
\hline Period & Belgium & France & Italy & Germany & Netherlands & Sweden & $\begin{array}{c}\text { Switzer- } \\
\text { land }\end{array}$ \\
\hline $1971 / 72$ & 2.11 & 2.99 & 5.31 & 1.43 & 1.60 & 0.48 & 0.61 \\
\hline $1972 / 73$ & 2.13 & 3.04 & 5.02 & 1.44 & 1.59 & 0.48 & 0.63 \\
\hline $1973 / 74$ & 2.18 & 2.98 & 4.84 & 1.61 & 1.71 & 0.47 & 0.68 \\
\hline $1974 / 75$ & 2.30 & 3.08 & 4.83 & 1.66 & 1.82 & 0.50 & 0.77 \\
\hline $1975 / 76$ & 2.16 & 3.03 & 3.84 & 1.59 & 1.72 & 0.47 & 0.80 \\
\hline $1976 / 77$ & 2.26 & 2.76 & 3.13 & 1.68 & 1.81 & 0.48 & 0.83 \\
\hline $1977 / 78$ & 2.49 & 2.86 & 2.75 & 1.88 & 1.98 & 0.45 & 0.99 \\
\hline $1978 / 79$ & 2.79 & 3.15 & 2.39 & 2.14 & 2.23 & 0.47 & 1.24 \\
\hline $1979 / 80$ & 2.91 & 3.27 & 4.17 & 2.27 & 2.32 & 0.49 & 1.25 \\
\hline $1980 / 81$ & 2.61 & 2.94 & 4.20 & 2.04 & 2.10 & 0.46 & 1.15 \\
\hline $1981 / 82$ & 2.06 & 2.31 & 3.24 & 1.74 & 1.77 & 0.37 & 1.07 \\
\hline $1982 / 83$ & 1.74 & 1.93 & 2.83 & 1.65 & 1.68 & 0.29 & 0.99 \\
\hline $1983 / 84$ & 1.54 & 1.67 & 2.47 & 1.52 & 1.52 & 0.26 & 0.95 \\
\hline $1984 / 85$ & 1.36 & 1.45 & 2.10 & 1.33 & 1.32 & 0.23 & 0.81 \\
\hline $1985 / 86$ & 1.66 & 1.78 & 2.39 & 1.64 & 1.64 & 0.27 & 1.00 \\
\hline $1986 / 87$ & 2.10 & 2.15 & 2.98 & 2.11 & 2.11 & 0.31 & 1.30 \\
\hline $1987 / 88$ & 2.33 & 2.34 & 3.18 & 2.35 & 2.36 & 0.34 & 1.45 \\
\hline $1988 / 89$ & 2.16 & 2.17 & 2.95 & 2.20 & 2.19 & 0.33 & 1.31 \\
\hline $1989 / 90$ & 2.28 & 2.28 & 3.10 & 2.30 & 2.30 & 0.33 & 1.34 \\
\hline 1990/91 & 2.57 & 2.55 & 3.41 & 2.58 & 2.57 & 0.36 & 1.54 \\
\hline $1991 / 92$ & 2.47 & 2.44 & 3.25 & 2.47 & 2.47 & 0.35 & 1.41 \\
\hline $1992 / 93$ & 5.32 & 5.26 & 5.88 & 5.31 & 5.32 & 0.63 & 2.98 \\
\hline $1993 / 94$ & 5.88 & 5.82 & 6.11 & 5.98 & 6.00 & 0.64 & 3.52 \\
\hline $1994 / 95$ & 7.76 & 7.48 & 7.06 & 7.74 & 7.79 & 0.79 & 4.71 \\
\hline $1995 / 96$ & 8.53 & 8.30 & 7.77 & 8.52 & 8.57 & 0.92 & 5.31 \\
\hline $1996 / 97$ & 8.02 & 7.94 & 7.96 & 8.01 & 8.03 & 0.92 & 4.83 \\
\hline $1997 / 98$ & 7.55 & 7.55 & 7.62 & 7.55 & 7.55 & 0.88 & 4.67 \\
\hline $1998 / 99$ & 8.43 & 8.43 & 8.42 & 8.44 & 8.42 & 0.93 & 5.21 \\
\hline $1999 / 00$ & 8.33 & 8.33 & 8.33 & 8.33 & 8.17 & 0.96 & 5.12 \\
\hline $2000 / 01$ & 7.43 & 7.43 & 7.43 & 7.43 & 7.43 & 0.85 & 4.85 \\
\hline $2001 / 02$ & 7.67 & 7.67 & 7.67 & 7.67 & 7.67 & 0.82 & 5.18 \\
\hline $2002 / 03$ & 8.98 & 8.98 & 8.98 & 8.98 & 8.98 & 0.98 & 6.07 \\
\hline $2003 / 04$ & 10.27 & 10.27 & 10.27 & 10.27 & 10.27 & 1.13 & 6.62 \\
\hline $2004 / 05$ & 11.01 & 11.01 & 11.01 & 11.01 & 11.01 & 1.21 & 7.15 \\
\hline $2005 / 06$ & 10.56 & 10.56 & 10.56 & 10.56 & 10.56 & 1.13 & 6.79 \\
\hline $2006 / 07$ & 11.48 & 11.48 & 11.48 & 11.48 & 11.48 & 1.25 & 7.13 \\
\hline $2007 / 08$ & 13.61 & 13.61 & 13.61 & 13.61 & 13.61 & 1.46 & 8.36 \\
\hline $2008 / 09$ & 14.32 & 14.29 & 14.29 & 14.29 & 14.29 & 1.38 & 9.28 \\
\hline
\end{tabular}

\begin{tabular}{|l|l|l|l|l|l|l|l|}
\hline $2009 / 10$ & 17.90 & 17.90 & 17.90 & 17.90 & 17.90 & 1.77 & 12.14 \\
\hline $2010 / 11$ & 22.03 & 22.03 & 22.03 & 22.03 & 22.03 & 2.42 & 17.00 \\
\hline $2011 / 12$ & 23.03 & 23.03 & 23.03 & 23.03 & 23.03 & 2.56 & 19.76 \\
\hline
\end{tabular}

Table 23a: Bilateral exchange rate between birr and major trade partners currency $(1971 / 72-2011 / 12)$.

\begin{tabular}{|c|c|c|c|c|c|c|c|c|}
\hline Period & UK & US & China & India & Japan & Korea $^{1}$ & Saudi Arabia & Egypt \\
\hline $1971 / 72$ & 6.05 & 2.39 & 1.01 & 0.32 & 0.01 & 0.01 & 0.56 & 5.56 \\
\hline $1972 / 73$ & 5.39 & 2.22 & 1.04 & 0.28 & 0.01 & 0.01 & 0.56 & 5.15 \\
\hline $1973 / 74$ & 4.94 & 2.07 & 1.06 & 0.26 & 0.01 & 0.01 & 0.58 & 5.06 \\
\hline $1974 / 75$ & 4.86 & 2.07 & 1.11 & 0.26 & 0.01 & 0.0040 & 0.59 & 5.31 \\
\hline $1975 / 76$ & 4.13 & 2.07 & 1.06 & 0.23 & 0.01 & 0.004 & 0.59 & 5.31 \\
\hline $1976 / 77$ & 3.54 & 2.07 & 1.09 & 0.23 & 0.01 & 0.004 & 0.59 & 5.31 \\
\hline $1977 / 78$ & 3.78 & 2.07 & 1.18 & 0.24 & 0.01 & 0.004 & 0.59 & 5.31 \\
\hline $1978 / 79$ & 4.15 & 2.07 & 1.28 & 0.25 & 0.01 & 0.004 & 0.62 & 4.13 \\
\hline $1979 / 80$ & 4.62 & 2.07 & 1.36 & 0.26 & 0.01 & 0.004 & 0.62 & 2.96 \\
\hline $1980 / 81$ & 4.74 & 2.07 & 1.32 & 0.26 & 0.01 & 0.004 & 0.62 & 2.96 \\
\hline $1981 / 82$ & 3.80 & 2.07 & 1.16 & 0.23 & 0.01 & 0.004 & 0.61 & 2.96 \\
\hline $1982 / 83$ & 3.35 & 2.07 & 1.05 & 0.21 & 0.01 & 0.004 & 0.60 & 2.96 \\
\hline $1983 / 84$ & 3.01 & 2.07 & 1.01 & 0.20 & 0.01 & 0.004 & 0.59 & 2.96 \\
\hline $1984 / 85$ & 2.54 & 2.07 & 0.77 & 0.17 & 0.01 & 0.004 & 0.58 & .96 \\
\hline $1985 / 86$ & 2.99 & 2.07 & 0.66 & 0.17 & 0.01 & 0.004 & .57 & .96 \\
\hline $1986 / 87$ & 3.16 & 2.07 & 0.56 & 0.16 & 0.01 & 0.004 & .55 & .96 \\
\hline $1987 / 88$ & 3.63 & 2.07 & 0.56 & 0.16 & 0.02 & 0.004 & .55 & .96 \\
\hline $1988 / 89$ & 3.56 & 2.07 & 0.56 & 0.14 & 0.02 & 0.004 & 5 & .96 \\
\hline $1989 / 90$ & 3.37 & 2.07 & 0.49 & 0.12 & 0.01 & 0.004 & 5 & .88 \\
\hline $1990 / 91$ & 3.85 & 2.07 & 0.41 & 0.11 & 0.02 & 0.004 & .55 & .84 \\
\hline $1991 / 92$ & 3.64 & 2.07 & 0.38 & 0.08 & 0.02 & 0.004 & 55 & 0.62 \\
\hline 1992 & 6.74 & 4.27 & 5 & 0 & 4 & 1 & 1.14 & .28 \\
\hline $1993 / 94$ & 7.65 & 5.11 & 0.73 & 0.16 & 0.05 & 0.01 & 1.36 & 1.52 \\
\hline $1994 / 95$ & 9.27 & 5.86 & 0.69 & 0.19 & 0.06 & 0.01 & 1.56 & 1.73 \\
\hline $1995 / 96$ & 9.75 & 6.31 & 0.76 & 0.18 & 0.06 & 0.01 & 1.68 & 1.86 \\
\hline $1996 / 97$ & 10.50 & 6.50 & 0.78 & 0.18 & 0.06 & 0.01 & 1.73 & 1.92 \\
\hline $1997 / 98$ & 11.32 & 6.88 & 0.83 & 0.18 & 0.05 & 0.01 & 1.84 & 2.03 \\
\hline $1998 / 99$ & 12.33 & 7.51 & 0.91 & 0.18 & 0.06 & 0.01 & 2.00 & 2.21 \\
\hline $1999 / 00$ & 12.97 & 8.15 & 0.98 & 0.19 & 0.08 & 0.01 & 2.17 & 2.38 \\
\hline $2000 / 01$ & 12.10 & 8.33 & 1.01 & 0.18 & 0.07 & 0.01 & 2.22 & 2.24 \\
\hline $2001 / 02$ & 12.34 & 8.54 & 1.03 & 0.18 & 0.07 & 0.01 & 2.28 & 1.94 \\
\hline $2002 / 03$ & 13.60 & 8.58 & 1.04 & 0.18 & 0.07 & 0.01 & 2.29 & 1.68 \\
\hline $2003 / 04$ & 15.00 & 8.62 & 1.04 & 0.19 & 0.08 & 0.01 & 2.30 & 1.40 \\
\hline $2004 / 05$ & 16.08 & 8.65 & 1.04 & 0.19 & 0.08 & 0.01 & 2.31 & 1.45 \\
\hline $2005 / 06$ & 15.43 & 8.68 & 1.08 & 0.19 & 0.08 & 0.01 & 2.32 & 1.51 \\
\hline $2006 / 07$ & 17.00 & 8.79 & 1.13 & 0.20 & 0.07 & 0.01 & 2.35 & 1.54 \\
\hline $2007 / 08$ & 18.52 & 9.24 & 1.27 & 0.23 & 0.08 & 0.01 & 2.47 & 1.69 \\
\hline $2008 / 09$ & 16.75 & 10.44 & 1.53 & 0.22 & 0.11 & 0.01 & 2.79 & 1.87 \\
\hline $2009 / 10$ & 20.36 & 12.89 & 1.89 & 0.28 & 0.14 & 0.01 & 3.44 & 2.32 \\
\hline 010/11 & 25.67 & 16.12 & 2.43 & 0.36 & 0.19 & 0.01 & 4.30 & 2.82 \\
\hline 2011/12 & 27.31 & 17.25 & 2.72 & 0.34 & 0.22 & 0.02 & 4.60 & 2.88 \\
\hline
\end{tabular}

Table 23b: Bilateral exchange rate between birr and major trade partners currency $(1971 / 72-2011 / 12)$.

by trade weighing bilateral exchange rates between the currency and its trading partners. The REERI is calculated as

$$
\sum_{i=1}^{18}\left\{(E i \times P) / P^{*}\right\} W i
$$

Where Ei is the bilateral exchange rate (currency per birr) of trading partner countries

$\mathrm{P}$ is the domestic price of Ethiopia 
Citation: Gebeyehu AB (2015) Major Agricultural Trade Volume in Ethiopia: Trade Balance and Exchange Rate Relations a Structural Break Analysis (Using Stability Chow Test, CUSUM and CUSUM Squared Residuals). J Glob Econ 3: 138. doi:10.4172/2375-4389.1000138

Page 10 of 10

$\mathrm{P}^{\star}$ foreign price

Wi is tarde partners' tarde weight

The REERI calculation thus takes 18 countries in to account of Below shows these countries (Tables 22, 23a and 23b).

\section{Acknowledgement}

I would like to express my sincere gratitude to Fikadu Belay, Zelalem Belay, and sister Hidassie Mokonnen who also provide the vital encouragement at the outset, without which it would never have been written well.

\section{References}

1. Anderson A, Sofia S (2010) How Does Depreciation in the Exchange Rate Affect Trade over Time? Jonkoping International Bussiness School, Jonkoping University.

2. Rose AK, Yellen JL (1989) Is There A J-Curve? Journal Of Monetary Economics 24: 53-68.

3. Petrović P, Mirjana G (2009) Exchange Rate And Trade Balance: J-Curve Effect In Serbia. Panoeconomicus 1: 23-41.

4. Brooks C (2002) Introductory econometrics for finance. Cambridge University Press, Cambridge.
Citation: Gebeyehu AB (2015) Major Agricultural Trade Volume in Ethiopia: Trade Balance and Exchange Rate Relations a Structural Break Analysis (Using Stability Chow Test, CUSUM and CUSUM Squared Residuals). J Glob Econ 3: 138. doi:10.4172/2375-4389.1000138
Submit your next manuscript and get advantages of OMICS Group submissions

Unique features:

User friendly/feasible website-translation of your paper to 50 world's leading languages Audio Version of published paper

Digital articles to share and explore

Special features:

- 400 Open Access Journals

30,000 editorial tean

21 days rapid review process

Quality and quick editorial, review and publication processing

Indexing at PubMed (partial), Scopus, EBSCO, Index Copernicus and Google Scholar etc

Sharing Option: Social Networking Enabled

Authors, Reviewers and Editors rewarded with online Scientific Credits

Better discount for your subsequent articles

Submit your manuscript at: http://www.scholarscentral.com/ 